\title{
International Approaches to Professional Development for Mathematics Teachers
}

Nadine Bednarz, Dario Fiorentini, and Rongin Huang. Ottawa, ON: University of Ottawa Press, 2011, pp. 263. ISBN 978-0-7766-0747-4 (pbk).

Atinuke Adeyemi

University of Windsor

\begin{abstract}
This book provides a rich description of the experiences and innovative approaches established in various countries to support the professional development of practising mathematics teachers. Many of these approaches are based on classroom context and took into consideration the practitioners' viewpoints. The analyses in various chapters help elucidate how the approaches articulate with practice, the contributions of teachers and teacher educators/researchers, and the fundamental theoretical framework directing the researchers. The chapters cover various aspects, including the main trends and issues in the education of practising mathematics teachers, the changes in their role during their careers, the learning that occurs between teachers and teacher educators/researchers, and the hidden power relations in the collaboration between the two groups. There are indications that the formal and informal experiences of mathematics teachers, all through their careers, can contribute to their professional development and that the viewpoints of teachers and their practical knowledge must be genuinely considered in order to construct critical professional development experiences. In essence, the book offers new ways of creating continuous professional development that would help bridge the gap between research and practice.
\end{abstract}

International Approaches to Professional Development for Mathematics Teachers, presents different international perspectives on alternative approaches and experiences established to support the professional development of mathematics teachers. It is written by a group of writers from different countries. It is organised into five parts with each part addressing a variety of issues-research, new theoretical viewpoints, reflections, and pragmatic experiences relating to the education and professional development of practising mathematics teachers in different countries. The book aims at informing a community of teachers, teacher educators and researchers of new options available to math educators and describes significant developments in the field. In the first chapter, mathematics teacher education is described as one that continues to emerge as an essential subfield of mathematics education. The chapter also discusses a past perspective on mathematics teacher education as a subfield and the major themes and issues in the education of practising mathematics teachers. Historically, teachers were portrayed purely as facilitators, instruments, and deficient professionals responsible for students' learning of mathematics. Hence, teacher education activity focussed on changing teaching practice in line with curriculum needs. Currently, changes have been noted as teachers are viewed as participants, partners, and researchers. In teacher education programs, teachers and teacher educators/ researchers learn from one another to enhance their practices. This learning helps teacher educators / researchers build not only new knowledge but also develop new theoretical models and insights; it systematizes their experiences.

In International Approaches to Professional Development for Mathematics Teachers, the experiences of teachers in their professional practices are proven to be different in various educational systems from different cultures. For example, the experiences that are denoted as teachers' leadership are described differently in China, Portugal, and the United States. In China, teachers' leadership refers to expert teachers who are developing through professional promotion (Li, Huang, Bao \& Fan, 2011). The responsibility of Chinese expert teachers include supervising novice teachers, giving public lessons, delivering public lectures and creating materials for teaching in 
order to promote other teachers' professional development. In Portugal, teachers' leadership refers to a subject leader working with other teachers in a school (Nunes, 2011). The responsibilities of Portuguese subject leader are to prepare and coordinate teachers' group meetings and supervise and evaluate other teachers' classroom practices. The situation is quite different in the United States where teachers' leadership refers to mentor teachers working with novice teachers (Rhodes \& Wilson, 2011). The main responsibility of experienced teachers is to provide advice, supervise and assist novice teachers to adapt to professional life. The mentors' roles could be shifted as "mentoring becomes a collaborative activity and a valuable learning opportunity for mentors and mentees” (Bednarz, Fiorentini \& Huang, 2011, p. 234).

Furthermore, the models of professional development are explained by some authors from a participatory point of view. These models are seen more as working with teachers rather than working on teachers. The collaborative group that involves researchers and teachers seems to be a crucial feature of the discussed approaches and experiences. For example, Ferreira and Miorim analysis of the evolution of collaborative group of teachers and researchers shows that shared experiences play a significant part in teachers' professional development and the learning of teacher educators/researchers. The implicit power relations between teachers and teacher educators was also noted in some chapters, which has the tendency of making collaboration challenging. From my experience in a collaborative inquiry project with in-service teachers and other teacher educators/researchers, the roles of the teachers changed from teachers to students as they strove to make sense of various ways to teach a unit in mathematics. Teachers' roles later changed from teachers to teachers in the classroom and teachers becoming researchers as they taught students in specified ways and collected data. The teachers' reflection on the experiences on collaborative work revealed a better understanding of the subject and growth in their professional lives.

In addition, there seems to be a relationship between reflection and change as diverse approaches and experiences indicate the significance of reflection in teachers' development. Written reflection, oral and written narratives, and self-regulated learning are examples of reflections suggested to be educative or that could promote teachers professional learning. In particular, written reflection on teaching and learning mathematics appears to help in-service and pre-service teachers. It brings to fore the relations in the practices of in-service teachers that may not be perceived by them and it provokes changes in their understanding of self and others. For pre-service teachers, it aids in the construction of their professional identities.

Apart from the discussion on the importance of reflection, some chapters concentrate on the mathematical preparation of in-service and pre-service teachers as well as providing alternatives to this preparation. The last chapters address the implementation of reforms and curricular changes in schools that are usually created as a "top down" process where programs developed by experts or researchers are presented to teachers to apply in their teaching. The "top down" model of development is shown to have no impact on mathematical teaching practices in schools. Hence, some authors call for new ways to approach the conceptualization of professional development that could be undertaken by researchers. I would add that the "top down" model of development, targeted at improving teachers' professional learning could be problematic as teachers have differing levels of interest, knowledge, and motivation, combined with students with different needs in their classrooms.

Ultimately, there are indications from the chapters that the formal and informal experiences of mathematics teachers, all through their careers, can contribute to their professional development; that the professional development of teachers are created within their practice; and that the viewpoints and practical knowledge of teachers must be genuinely considered for the creation of critical professional development experience. I would therefore submit that continuous research on the analysis of these experiences is very essential as it would help teachers, teacher educators, and researchers grow in life-long learning and professionally too.

This book, in my view, underscores the importance of professional development of practising teachers as a vital element of the "continuum of learning of teachers throughout their careers" (Broad \& Evans, 2006, p. 3). It contributes to the literature that shows that collaboration, learning with and from other teachers, and shared inquiry are essential to professional development of teachers. Also, it fits other writings that revealed that effective professional development initiatives for teachers incorporated opportunities for reflection which help to transform teaching practice (Saylor \& Johnson, 2014). It is beneficial for teachers, teacher educators, and 
researchers who are looking for ways to support the professional development of pre-service and in-service teachers. Significantly, it offers academic literature the characteristics of many different exemplary experiences and approaches from diverse countries that can be used to promote such development, including the challenges that may be encountered when using some of the approaches. The book reinforces my belief on the power of collaboration as a means to enhance in-service teachers' effectiveness to teach their subjects. It also brings to my awareness that time and resources are needed for effective professional learning and professional development initiatives for teachers.

\section{References}

Bednarz, N., Fiorentini, D., \& Huang, R. (2011). Education of practising teachers, professional life, and development of mathematics teachers. In N. Bednarz, D. Fiorentini, \& R. Huang (Eds.), International approaches to professional development for mathematics teachers (pp. 232-246). Ottawa, ON: University of Ottawa Press.

Broad, K. \& Evans, M. (2006). Initial teacher education program: A review of literature on professional development content and delivery modes for experienced teachers. Report for the Ontario Ministry of Education.

Ferreira, A., C., \& Miorim (2011). Collaborative work and the professional development of mathematics teachers: Analysis of a Brazilian experience. In N. Bednarz, D. Fiorentini, \& R. Huang (Eds.), International approaches to professional development for mathematics teachers (pp. 137-149). Ottawa, ON: University of Ottawa Press.

Li, Y., Huang, R., Bao, J., \& Fan, Y. (2011). Facilitating mathematics teachers' professional development through ranking and promotion in mainland China. In N. Bednarz, D. Fiorentini, \& R. Huang (Eds.), International approaches to professional development for mathematics teachers (pp. 72-85). Ottawa, ON: University of Ottawa Press.

Nunes, C. C. (2011). The professional development of mathematics teacher in the role of a subject leader. In N. Bednarz, D. Fiorentini, \& R. Huang (Eds.), International approaches to professional development for mathematics teachers (pp. 52-61). Ottawa, ON: University of Ottawa Press.

Rhodes, G., \& Wilson, S. (2011). Mentoring as professional development: A case from secondary-level mathematics. In N. Bednarz, D. Fiorentini, \& R. Huang (Eds.), International approaches to professional development for mathematics teachers (pp. 6271). Ottawa, ON: University of Ottawa Press.

Saylor, L., \& Johnson, C. C. (2014). The role of reflection in elementary mathematics and science teachers' training and development: A meta-synthesis. School Science \& Mathematics, 114(1), 30-39. 